\title{
IMENINGKATKAN HASIL BELAJAR SISWA PADA MATERI VOLUME KUBUS DAN BALOK MELALUI METODE KERJA KELOMPOK MENGGUNAKAN MEDIA KUBUS SATUAN
}

Improving Student Learning Outcomes on Cube and Block Volume Materials Through Group Work Method Using Unit Cube Media Marline Silvi Diana

SDN 6 Panarung, Palangkaraya, Kalimantan Tengah, Indonesia.

\section{ABSTRAK}

\section{ARTIKEL INFO}

Diterima

Agustus 2021

Dipublikasi September 2021

\begin{abstract}
Mata pelajaran matematika memegang peranan penting untuk membantu peserta didik mencapai kompetensi yang lebih luas.Materi matematika yang diajarkan di sekolah harus dipilih dan disesuaikan dengan tujuan pendidikan, kompetensi dan kepribadian peserta didik sesuai dengan tututan perkembangan seiring dengan kemajuan ilmu teknologi.

Penelitian ini menggunakan Penelitian Tindakan Kelas. PTK diangkat dari persoalan- persoalan yang dihadapi guru di kelas. Hasil penelitiannya dapat dimanfaatkan secara langsung untuk kepentingan meningkatkan kualitas meningkatkan kegiatan belajar-mengajar di kelas atau untuk meningkatkan kualitas pembelajaran. Prosedur pelaksanaannya dapat dimulai Dari Perencanaan, Tindakan atau observasi, Refleksi dan Hasil.

Subjek tindakan pada penelitian ini adalah siswa-siswi Kelas $\vee$ SDN-6 Panarung. Jumlah siswa Kelas V SDN-6 Panarung yaitu sebanyak 22 (dua puluh) orang; yang terdiri dari 14 (empat belas) orang siswa laki-laki dan 8 (delapan) orang siswa perempuan. Jadi jumlah subjek penelitian sebanyak 22 Orang. Siklus Penelitian Rancangan ada Siklus I dan Siklus II.
\end{abstract}

Kata Kunci : Media Kubus dan Balok, Metode Kerja Kelompok

\begin{abstract}
Mathematics subjects play an important role in helping students achieve broader competencies. Mathematics materials taught in schools must be selected and adapted to the educational goals, competencies and personalities of students in accordance with the demands of development along with advances in technology.

This research uses Classroom Action Research. CAR is raised from the problems faced by teachers in the classroom. The results of his research can be used directly for the benefit of improving the quality of improving teaching and learning activities in the classroom or to improve the quality of learning. The implementation procedure can be started from planning, action or observation, reflection and results.

The subjects of the action in this study were the fifth grade students of SDN-6 Panarung. The number of Class V students at SDN-6 Panarung is as many as 22 (twenty) people; consisting of 14 (fourteen) male students and 8 (eight) female students. So the number of research subjects was 22 people. The Design Research Cycle has Cycle I and Cycle II.
\end{abstract} marlinesilvidiana7।@gmail .com

Keywords: Cube and Block Media, Group Working Method

(c) Universitas Muhammadiyah Palangkaraya 


\section{Jurnal Pendidikan Teknologi Informasi}

\section{PENDAHULUAN}

Matematika adalah satu mata pelajaran yg diajari peserta didik saat pada Sekolah Dasar (SD). Pengetahuan matematika pada Sekolah Dasar akan menjadi dasar buat menelaah matematika di Sekolah Menengah Pertama, SMA bahkan jenjang pendidikan berikutnya. Matematika artinya suatu ilmu yang mampu melatih peserta didik pada menggunakan penalaran logis, sistematis, kritis, serta teliti.Ruseffendi (Ansari 2009:tiga) berpendapat bahwa "Matematika merupakan bahasa symbol, ilmu deduktif yg tidak menerima verifikasi secara induktif; ilmu tentang pola keteraturan, dan struktur yang terorganisasi, mulai dari unsur yang tidak didefenisikan, ke aksioma atau postulat dan akhirmya kedalil".

Matematika sudah dikembangkan begitu pesat serta luas pemakaiannya, antara lain buat tahu kebutuhan praktis dan memecahkan problem dalam kehidupan sehari-hari.Mata pelajaran matematika memegang peranan krusial buat membantu siswa mencapai kompetensi yang lebih luas.Materi matematika yang diajarkan di sekolah wajib dipilih dan diubahsuaikan menggunakan tujuan pendidikan, kompetensi serta kepribadian peserta didik sesuai dengan tututan perkembangan seiring dengan kemajuan ilmu teknologi.

Beberapa upaya dilakukan sang guru agar yang akan terjadi belajar yg di peroleh peserta didik mampu meningkat. poly teori dan prinsip-prinsip belajar yg di kemukakan oleh para pakar yg satu menggunakan yang lain memiliki persamaan serta disparitas. asal berbagai prisip belajar tadi ada beberapa prinsip yang cukup berlaku umum yg bisa dipergunakan menjadi dasar pada upaya pembelajaran, baik bagi peserta didik yg perlu menaikkan upaya belajarnya juga bagi guru di upaya menaikkan belajarnya.Prinsip tersebut antara lain ialah memakai menggunakan metode.Metode artinya bagian berasal taktik
belajar.Metode dipilih sesuai taktik kegiatan yang sudah dipilih dan diterapkan. Metode artinya cara yang pada bekerja adalah alat buat mencapai tujuan belajar. keliru satu penyebab adalah di ketika belajar pengajar kurang menggunakan pendekatan/metode yang bervariasi, sehingga siswa kurang memahami dan tidak berperan aktif pada kegiatan belajar mengajar Matematika.

Salah satu cara buat membangkitkan aktivitas siswa pada proses pembelajaran adalah menggunakan memakai Pendekatan/metode yang tepat yakni pembelajaran bisa berakibat peserta didik sebagai subjek yang berupaya menggali sendiri, memecahkan sendiri problem-dilema berasal suatu konsep yang dipelajari, sedangkan guru lebih banyak bertindak menjadi motivator dan fasilitator. berasal Gagne (Susanto, 2013:I) "belajar ialah suatu proses dimana suatu organisme berubah perilakunya menjadi akibat pengalaman. Belajar dan mengajar merupakan dua konsep yang tak bisa dipisahkan satu sama lain, 2 konsep ini menjadi terpadu di suatu aktivitas dimana terjadi korelasi antara pengajar memakai peserta didik, dan peserta didik menggunakan peserta didik yg lain waktu pembelajaran. menurut Susanto (2013:lima) mengatakan bahwa "akibat belajar adalah perubahan-perubahan yg terjadi pada diri peserta didik, baik yang menyangkut aspek kognitif, afektif, serta psikomotor menjadi yg akan terjadi dari kegiatan belajar". Sedangkan berdasarkan Sudjana (2012:tiga) :hasil belajar siswa pada hakikatnya ialah perubahan tingkah laku . Tingkah laku menjadi yang akan terjadi belajar dalam pengertian yg luas mencangkup bidang kognitif, afektif, serta psikomotoris.oleh sebab itu, dalam evaluasi hasil belajar, peranan tujuan instruksional yang beri rumusan kemampuan serta tingkah laku yang diinginkan dikuasai peserta didik menjadi unsur penting sebagi dasar dan acuan penilaian.Menurut ensiklopedia bebas (dalam Hariwijaya, 2009:30) Matematika "berasal dari 


\section{Jurnal Pendidikan Teknologi Informasi}

kata mathemadalam bahasa Yunani yang diartikan sebagai "sains, ilmu pengetahuan, atau belajar" juga mathematikos yang diartikan sebagai “suka belajar". pengertian dapat disimpulkan bahwa matematika merupakan suatu bidang ilmu yang mencakup berbagai bilangan dan angka, terstruktur, logis, mulai dari hal yang paling mudah hingga yang paling rumit.

Sedangkan dari Asma (Arends 2012:38)

"Kerja kelompok ialah mendasarkan di suatu ide bahwa peserta didik bekerja sama dalam belajar grup dan sekaligus masing-masing bertanggung jawab pada kegiatan belajar anggota kelompoknya, sehingga seluruh anggota kelompok bisa mengusai materi pelajaran menggunakan baik". sesuai saat yg dipergunakan metode kerja gerombolan dibagi menjadi 3 macam yaitu: Kerja grup berjangka pendek, Kerja gerombolan berjangka panjang serta Kerja gerombolan campuran.

Tujuan dan manfaat dari penggunaan metode kerja kelompok adalah sebagai berikut:
a. Menaikkan motivasi serta kemampuan kerja sama diantar para peserta didik.
b. Melatih ketertiban sosial emosional serta intelektual para peserta didik dalam proses belajar mengajar.

c. Menaikkan perhatian terhadap proses dan yang akan terjadi proses belajar mengajar secara seimbang.

Penerapan metode belajar memakai memakai kerja kelompok bisa memperdalam pemahaman siswa terhadap potensi yang dimiliki menjadi akibatnya menggunakan melaksanakan aktivitas-aktivitas yang banyak melibatkan hubungan dan kolaborasi menggunakan orang lain maka hal tadi meransang peserta didik buat berfikir aktif serta mengeluarkan pendapat memakai leluasa mengungkapkan pandangan baru serta gagasannya.

Penerapan metode kerja kelompok menurut pendapat Sondang (lbrahim, dkk
2009:10) melalui beberapa tahap-tahap atau fase sebagai berikut:

a. Menyampaikan tujuan dan motivasi belajar.

b. Menyajikan informasi.

c. Mengorganisasikan peserta didik kedalam kelompok-kelompok belajar.

d. Membimbing kelompok bekerja dan belajar.

e. Evaluasi

f. Memberikan penghargaan.

Media kubus satuan ialah media yang digunakan oleh pengajar untuk mempermudah peserta didik mengerti bagaimana mencari volume kubus serta Balok menggunakan memakai rumus. Sebelum memakai rumus maka pengajar memberikan contoh atau teknik menghitung volume Kubus dan Balok menggunakan menghitung banyaknya jumlah satuan kubus. model-model bangun kubus dapat diambil berasal lingkungan yg terdapat pada kurang lebih sekolah contohnya Lemari, Meja Kelas yang terdapat lacinya, kotak Kapur, kotak susu dan lain-lain.

\section{METODOLOGI PENELITIAN}

Penelitian ini menggunakan Penelitian Tindakan Kelas. PTK diangkat dari persoalanpersoalan yang dihadapi guru di kelas. Hasil penelitiannya dapat dimanfaatkan secara langsung untuk kepentingan meningkatkan kualitas meningkatkan kegiatan belajarmengajar di kelas atau untuk meningkatkan kualitas pembelajaran. Prosedur pelaksanaannya dapat dimulai Dari Perencanaan, Tindakan atau observasi, Refleksi dan Hasil.

Subjek tindakan pada penelitian ini adalah siswa-siswi Kelas V SDN-6 Panarung. Jumlah siswa Kelas V SDN-6 Panarung yaitu sebanyak 22 (dua puluh) orang; yang terdiri dari 14 (empat belas) orang siswa laki-laki dan 8 (delapan) orang siswa perempuan. Jadi jumlah subjek penelitian sebanyak 22 Orang. Siklus Penelitian Rancangan ada Siklus I dan Siklus II. 
HASIL DAN PEMBAHASAN

Dalam penelitian ini peneliti menggunakan instrumen atau pengumpulan data.
Tabel I. Data Lembar Pengamatan Rencana Pelaksanaan Pembelajaran (RPP) dan Pelaksanaan Pembelajaran pada Mata Pelajaran Matematika di Kelas V SDN-6 Panarung Pada Siklus I dan Siklus 2.

\begin{tabular}{|c|c|c|c|c|c|c|c|c|c|c|c|}
\hline \multirow{3}{*}{ No } & \multirow{3}{*}{ Kegiatan Guru } & \multicolumn{10}{|c|}{ Kriteria Penilaian } \\
\hline & & \multicolumn{5}{|c|}{ Siklus 1} & \multicolumn{5}{|c|}{ Siklus 2} \\
\hline & & $\mathbf{A}$ & $\mathbf{B}$ & $\mathbf{C}$ & $\mathbf{D}$ & $\mathbf{E}$ & $\mathbf{A}$ & $\mathbf{B}$ & $\mathbf{C}$ & $\mathbf{D}$ & $\mathbf{E}$ \\
\hline 1 & $\begin{array}{l}\text { Kemampuan Guru melakukan apersepsi } \\
\text { (membuka pelajaran). }\end{array}$ & & 75 & & & & 85 & & & & \\
\hline 2 & $\begin{array}{l}\text { Kemampuan Guru menyampaikan tujuan } \\
\text { pembelajaran. }\end{array}$ & & 80 & & & & 90 & & & & \\
\hline 3 & $\begin{array}{l}\text { Kemampuan Guru memberikan motivasi dan } \\
\text { penguatan. }\end{array}$ & & 80 & & & & 85 & & & & \\
\hline 4 & Kesesuaian RPP yang disusun guru. & 85 & & & & & 95 & & & & \\
\hline 5 & Guru memberikan umpan balik. & & 70 & & & & & 80 & & & \\
\hline 6 & Siswa aktif bertanya. & & & 65 & & & & 70 & & & \\
\hline 7 & Siswa aktif menjawab pertanyaan guru. & & & 65 & & & & 75 & & & \\
\hline 8 & Interaksi guru dengan siswa. & & 70 & & & & & 70 & & & \\
\hline 9 & Interaksi siswa dengan siswa. & & 70 & & & & & 75 & & & \\
\hline 10 & $\begin{array}{l}\text { Guru menggunakan alat peragaatau media } \\
\text { pembelajaran. }\end{array}$ & & & 60 & & & & 80 & & & \\
\hline 11 & $\begin{array}{l}\text { Kemampuan Guru dalam menjelaskan materi } \\
\text { pembelajaran. }\end{array}$ & & 80 & & & & 85 & & & & \\
\hline 12 & $\begin{array}{l}\text { Kemampuan Guru dalam merancang dan } \\
\text { membuat pertanyaan pada Lembar Kerja Siswa } \\
\text { yang sesuai dengan materi pembelajaran. }\end{array}$ & & 75 & & & & 85 & & & & \\
\hline 13 & $\begin{array}{l}\text { Kemampuan Guru dalam memimpin dan } \\
\text { mengatur siswa dalam pembelajaran dengan } \\
\text { menggunakan Metode Kerja Kelompok }\end{array}$ & & 75 & & & & 90 & & & & \\
\hline 14 & $\begin{array}{l}\text { Kemampuan siswa dalam mengikuti } \\
\text { pembelajaran dengan menggunakan Metode } \\
\text { Kerja Kelompok }\end{array}$ & & 70 & & & & 90 & & & & \\
\hline 15 & Guru mengadakan evaluasi atau penilaian & & 75 & & & & 85 & & & & \\
\hline 16 & Kemampuan Guru dalam menutup pelajaran. & & 75 & & & & 90 & & & & \\
\hline & $\begin{array}{l}\text { nber data Penilaian RPP } \\
\text { terangan : } \\
\text { at Baik Rentangan Skor }=85-100\end{array}$ & $\begin{array}{l}\text { gur } \\
\text { keg } \\
\text { pen }\end{array}$ & & ר. & & ILas & & & & & $\begin{array}{l}\text { Jan } \\
\text { ses }\end{array}$ \\
\hline
\end{tabular}

$B=$ Baik Rentangan Skor $70-84$

$C=$ Cukup Baik Rentangan Skor $=56-69$

$D=$ Kurang Baik Rentangan Skor $=40-55$

$E=$ Sangat Kurang Baik Rentangan Skor $=0$-39

Berdasarkan data pada tabel I di atas dapat disimpulkan bahwa pada siklus 2 Kemampuan Guru dalam menutup pelajaran mendapat Nilai 90 dengan Kriteria Sangat Baik.Dari data tersebut di atas terdapat peningkatan nilai yaitu sebesar 15 poin.

Lembar pengamatan atau observasi adalah instrumen pengambilan data melalui pengamatan kegiatan pelaksanaan pembelajaran yang dilakukan oleh seorang kegiatan pembelajaran pada penelitian ini artinya dengan penerapan pembelajaran menggunakan metode kerja kelompok memakai media kubus satuan pada kelas $\mathrm{V}$ Sekolah Dasar Negeri-6 Panarung. Adapun materi pelajaran di penelitian yg menerapkan metode kerja kelompok memakai media kubus satuan pada mata pelajaran Matematika pada Kelas V SDN-6 Panarung di materi materi volume kubus dan balok. Analisis data disimpulkan bahawa pada pelaksanaan pembelajaran siklus 2 menggunakan memanfaatkan metode kerja grup menggunakan media kubus satuan pada mata 


\section{Jurnal Pendidikan Teknologi Informasi}

pelajaran Matematika buat materi materi volume kubus serta balok di kelas $V$ SDN-6 Panarung; Keaktifan siswa pada melakukan pengamatan tentang bangun ruang mendapat nilai menggunakan kriteria Sangat Baik dan Baik. Hal ini terbukti buat kriteria nilai Sangat Baik sebesar 8 atau 40\%, dan nilai Baik sebanyak 12 atau $50 \%$. Konsentrasi peserta didik dalam mendengarkan penjelasan pengajar mendapat nilai menggunakan kriteria Sangat Baik serta Baik. Hal ini terbukti buat kriteria nilai Sangat Baik sebanyak 6 atau 30\%, serta nilai Baik sebesar 12 atau $60 \%$. Motivasi siswa dalam mengikuti kegiatan pembelajaran menerima nilai menggunakan kriteria Sangat Baik dan Baik. Hal ini terbukti buat kriteria nilai Sangat Baik sebanyak 7 atau 35\%, dan nilai Baik sebesar 15 atau $65 \%$. Kreativitas siswa pada mengimplementasikan rumus volume kubus serta balok mendapat nilai menggunakan kriteria Sangat Baik serta Baik. $\mathrm{Hal}$ ini terbukti buat kriteria nilai Sangat Baik sebesar 10 atau 50\%, dan nilai Baik sebesar 9 atau $45 \%$; serta cukup sebesar I orang atau $5 \%$.

\section{KESIMPULAN}

Adapun yang menjadi kesimpulan pada Penelitin Tindakan Kelas adalah Teknik Atau Cara Menerapkan Metode Kerja Kelompok Menggunakan Media Kubus Satuan Pada Mata Pelajaran Matematika Di Kelas V SDN-6 Panarung adalah sebagai berikut: I)Menyusun Rencana Pelaksanaan Pembelajaran (RPP) yang sesuai dengan Standar Kompetensi, Kompetensi Dasar, Indikator, Tujuan pembelajaran dan Materi Pembelajaran; 2)Melaksanakan kegiatan pembelajaran sesuai dengan Rencana Pelaksanaan Pembelajaran (RPP) yang sudah disusun. 3)Menyusun Lembar Kerja Siswa (LKS) sesuai dengan materi pembelajaran. Dan 4)Membuat Laporan Penelitian Tindakan Kelas (PTK) dengan menganalisis data nilai-nilai dari hasil
Lembar Kerja Siswa (LKS) Pada Siklus I dan Siklus 2.

Penggunaan Metode Kerja kelompok menggunakan Media Kubus Satuan dapat meningkatkan yang akan terjadi Belajar siswa pada Mata Pelajaran Matematika di Kelas V SDN-6 Panarung. Hal ini terbukti dengan jumlah nilai matematika artinya 12,10 menggunakan nilai homogen-homogen kelas mata Pelajaran Matematika sesuai hasil lembar Kerja Siswa (LKS) di daur I adalah 60,lima dan jumlah nilai Matematika pada daur 2 ialah 14,40 dengan nilai homogen-rata Kelas mata Pelajaran Matematika di siklus 2 adalah sebesar 72,00 terbukti terdapat peningkatan sebesar II,5.

\section{DAFTAR PUSTAKA}

Arikunto Suharsimi, Suhardjono, Supardi. 2008. Penelitian Tindakan Kelas. Jakarta : Penerbit Bumi Aksara.

Ali, Mohammad. 1997. Penelitian Pendidikan Prosedur dan Strategi. Bandung Angkasa

Arikunto Suharsimi.1989. Manajemen Penelitian. Dirjen DIKTI P2LPTK, Jakarta

Burhan Mustaqim dan Ary Astuty, 2008.Depdiknas DirjenDikdasmen dan Dirjen Pembinaan Tk dan SD, 2009.Model Bahan Ajar Matematika Untuk Sekolah Dasar.Jakarta.

Depdiknas Dirjendikdasmen Direktorat Tenaga Kependidikan, 2004. Interaksi Belajar Mengajar, Jakarta.

Depdiknas Dirjendikdasmen Direktorat Tenaga Kependidikan. 2004. DasarDasar Pembelajaran, Jakarta.

Dimyati dan Mudjiono. 1999. Belajar dan Pembelajaran. Jakarta: Rineka Cipta.

OemarHamalik.(2006). Proses Belajar Mengajar. Bandung: Bumi Aksara.

Pustekkom,2009. Pemanfaatan Internet Dalam Pembelajaran. Jakarta: Depdiknas.

Riadin Agung dan Uswatun Nisa. 2017. Upaya Meningkatkan Hasil Belajar Matematika Dengan Menerapkan Model Pembelalajaran Langsung Menggunakan Media Mobil Garis 
Jurnal Pendidikan Teknologi Informasi

Bilangan Tahun Pelajaran 2016/2017.

Pedagogik: Jurnal Pendidikan. 12:2(28-

33).

Setyawan Dedy dan Chandra Anugrah Putra. 2020. Pengaruh Logic-Mathematic Intelligence Dan Cognitive Load Theory Terhadap Hasil Belajar Matematika. Jurnal Holistika. 4:2 (96100).

Suhardjono. 2009.Pertanyaan Dan Jawaban di Sekitar Penelitian Tindakan Kelas Dan Sekolah. Universitas Negeri Malang : Penerbit Cakrawala Indonesia LP3. 